\title{
The Plasma Insulin and Growth Hormone Response to Oral Glucose: Diurnal and Seasonal Observations in the Antarctic
}

\author{
I. T. Campbell, R. J. Jarrett, P. Rutland and L. Stimmler \\ British Antarctic Survey and Guy's Hospital, London, England \\ Received: August 22, 1974 and in revised form: December 23, 1974
}

\begin{abstract}
Summary. Plasma insulin and growth hormone levels were measured during morning and afternoon oral glucose tolerance tests performed on 12 young men at three monthly intervals in the Antarctic. No diurnal or seasonal differences in growth hormone levels were found. However there were
\end{abstract}

diurnal and seasonal variations in the blood glucose/plasma insulin relationship.

Key words: Plasma insulin, oral glucose tolerance, diurnal variation, seasonal variation.
Oral glucose tolerance tests were done in the morning (08.00 hrs) and afternoon (16.00 hrs) on a population of scientists and technicians spending a year (1972) on an Antarctic Base. Tests were done four times in the year as described in the previous paper [2], at midwinter, midsummer and the two equinoxes. Venous blood was taken into EDTA tubes and stored on ice until the end of the test. The blood was centrifuged and the supernatant plasma removed and frozen for subsequent shipment back to the U.K.

\section{Methods}

Plasma insulin was measured on all samples by a double antibody immunoassay [9]. Plasma growth hormone was measured on fasting and $2 \frac{1}{2}$ hour samples by a similar immunoassay [6]. All samples from one subject were analysed within one assay.

\section{Results \\ Insulin}

Mean insulin levels for each time point in the glucose tolerance test, morning and afternoon for all four seasons are shown in Table 1 with the corresponding mean glucose levels. The highest insulin levels and the greatest diurnal variation occurred in March (Autumn). In subsequent tests, there was a progressive decline in levels; in December both the absolute levels of insulin and their diurnal variation were less than in previous tests.

The relationship between insulin and glucose levels is shown in Figs. 1 and 2. Mean levels were calculated for each time point in the glucose tolerance test and
Table 1. Mean plasma insulin levels ( \pm SEM) and corresponding mean blood sugar levels in glucose tolerance tests carried out during March, June, September and December at $08.00 \mathrm{hrs}$ and $16.00 \mathrm{hrs}$

\begin{tabular}{|c|c|c|c|c|c|}
\hline & $\begin{array}{l}\text { Mean } \\
\text { Blood } \\
\text { Sugar } \\
\text { (mg/100 } \\
\text { ml) }\end{array}$ & $\begin{array}{l}\text { Mean } \\
\text { Plasma } \\
\text { Insulin } \\
(\mu \mathrm{U} / \mathrm{ml})\end{array}$ & & $\begin{array}{l}\text { Mean } \\
\text { Blood } \\
\text { Sugar } \\
(\mathrm{mg} / 100 \\
\mathrm{ml})\end{array}$ & $\begin{array}{l}\text { Mean } \\
\text { Plasma } \\
\text { Insulin } \\
(\mu \mathrm{U} / \mathrm{ml})\end{array}$ \\
\hline March & & & June & & \\
\hline $\begin{array}{c}0800 \mathrm{hrs} \\
\text { Fast. } \\
0.5 \mathrm{hr} \\
1.0 \mathrm{hr} \\
1.5 \mathrm{hr} \\
2.0 \mathrm{hr} \\
2.5 \mathrm{hr}\end{array}$ & $\begin{array}{l}56 \pm 3 \\
94 \pm 7 \\
73 \pm 6 \\
57 \pm 5 \\
45 \pm 4 \\
54 \pm 2\end{array}$ & $\begin{array}{l}15 \pm 5 \\
60 \pm 32 \\
55 \pm 25 \\
29 \pm 13 \\
16 \pm 5 \\
15 \pm 4\end{array}$ & $\begin{array}{l}\text { Fast. } \\
0.5 \mathrm{hr} \\
1.0 \mathrm{hr} \\
1.5 \mathrm{hr} \\
2.0 \mathrm{hr} \\
2.5 \mathrm{hr}\end{array}$ & $\begin{array}{l}57 \pm 3 \\
95 \pm 7 \\
96 \pm 8 \\
66 \pm 9 \\
54 \pm 8 \\
53 \pm 5\end{array}$ & $\begin{array}{l}15 \pm 5 \\
48 \pm 33 \\
54 \pm 27 \\
33 \pm 12 \\
20 \pm 8 \\
15 \pm 5\end{array}$ \\
\hline $\begin{array}{c}1600 \mathrm{hrs} \\
\text { Fast. } \\
0.5 \mathrm{hr} \\
1.0 \mathrm{hr} \\
1.5 \mathrm{hr} \\
2.0 \mathrm{hr} \\
2.5 \mathrm{hr}\end{array}$ & $\begin{array}{l}52 \pm 3 \\
85 \pm 5 \\
95 \pm 8 \\
77 \pm 7 \\
67 \pm 5 \\
52 \pm 2\end{array}$ & $\begin{array}{l}15 \pm 6 \\
45 \pm 34 \\
50 \pm 26 \\
37 \pm 20 \\
28 \pm 15 \\
15 \pm 4\end{array}$ & $\begin{array}{l}\text { Fast. } \\
0.5 \mathrm{hr} \\
1.0 \mathrm{hr} \\
1.5 \mathrm{hr} \\
2.0 \mathrm{hr} \\
2.5 \mathrm{hr}\end{array}$ & $\begin{array}{l}56 \pm 2 \\
89 \pm 5 \\
98 \pm 8 \\
84 \pm 9 \\
66 \pm 7 \\
56 \pm 4\end{array}$ & $\begin{array}{l}12 \pm 3 \\
30 \pm 15 \\
36 \pm 14 \\
33 \pm 16 \\
22 \pm 8 \\
13 \pm 4\end{array}$ \\
\hline Septembe & & & Decem & & \\
\hline $\begin{array}{c}0800 \mathrm{hrs} \\
\text { Fast. } \\
0.5 \mathrm{hr} \\
1.0 \mathrm{hr} \\
1.5 \mathrm{hr} \\
2.0 \mathrm{hr} \\
2.5 \mathrm{hr}\end{array}$ & $\begin{array}{l}56 \pm 2 \\
92 \pm 6 \\
91 \pm 8 \\
66 \pm 5 \\
55 \pm 3 \\
52 \pm 3\end{array}$ & $\begin{array}{l}10 \pm 5 \\
30 \pm 14 \\
36 \pm 15 \\
24 \pm 10 \\
16 \pm 7 \\
10 \pm 4\end{array}$ & $\begin{array}{l}\text { Fast. } \\
0.5 \mathrm{hr} \\
1.0 \mathrm{hr} \\
1.5 \mathrm{hr} \\
2.0 \mathrm{hr} \\
2.5 \mathrm{hr}\end{array}$ & $\begin{array}{l}47 \pm 2 \\
78 \pm 5 \\
59 \pm 3 \\
46 \pm 4 \\
42 \pm 3 \\
41 \pm 3\end{array}$ & $\begin{array}{l}14 \pm 6 \\
31 \pm 16 \\
27 \pm 15 \\
20 \pm 7 \\
13 \pm 5 \\
12 \pm 4\end{array}$ \\
\hline $\begin{array}{c}1600 \mathrm{hrs} \\
\text { Fast. } \\
0.5 \mathrm{hr} \\
1.0 \mathrm{hr} \\
1.5 \mathrm{hr} \\
2.0 \mathrm{hr} \\
2.5 \mathrm{hr}\end{array}$ & $\begin{array}{l}51 \pm 3 \\
88 \pm 6 \\
96 \pm 6 \\
77 \pm 8 \\
62 \pm 7 \\
52 \pm 3\end{array}$ & $\begin{array}{l}12 \pm 5 \\
27 \pm 14 \\
30 \pm 10 \\
26 \pm 10 \\
20 \pm 7 \\
15 \pm 5\end{array}$ & $\begin{array}{l}\text { Fast. } \\
0.5 \mathrm{hr} \\
1.0 \mathrm{hr} \\
1.5 \mathrm{hr} \\
2.0 \mathrm{hr} \\
2.5 \mathrm{hr}\end{array}$ & $\begin{array}{l}48 \pm 3 \\
73 \pm 6 \\
77 \pm 8 \\
64 \pm 6 \\
50 \pm 4 \\
48 \pm 3\end{array}$ & $\begin{array}{l}12 \pm 5 \\
27 \pm 9 \\
30 \pm 12 \\
23 \pm 6 \\
17 \pm 6 \\
13 \pm 4\end{array}$ \\
\hline
\end{tabular}


regression equations and correlation coefficients calculated for the glucose/insulin relationship. The correlation between insulin and glucose was in each instance highly significant $(p<0.001)$, but there was some seasonal variation in the slope of the insulin/ glucose regression. This can be seen in Fig. 2, the largest difference being between March and December for the morning and, for the afternoon, between the actual values and glucose/insulin ratios calculated from the mean of all glucose and insulin measurements (Table 2).

Comparing morning and afternoon (Table 2), the glucose/insulin ratio was lower in the morning in each season. Comparing the seasons, the glucose/insulin ratios were lowest in March both in the morning and afternoon.
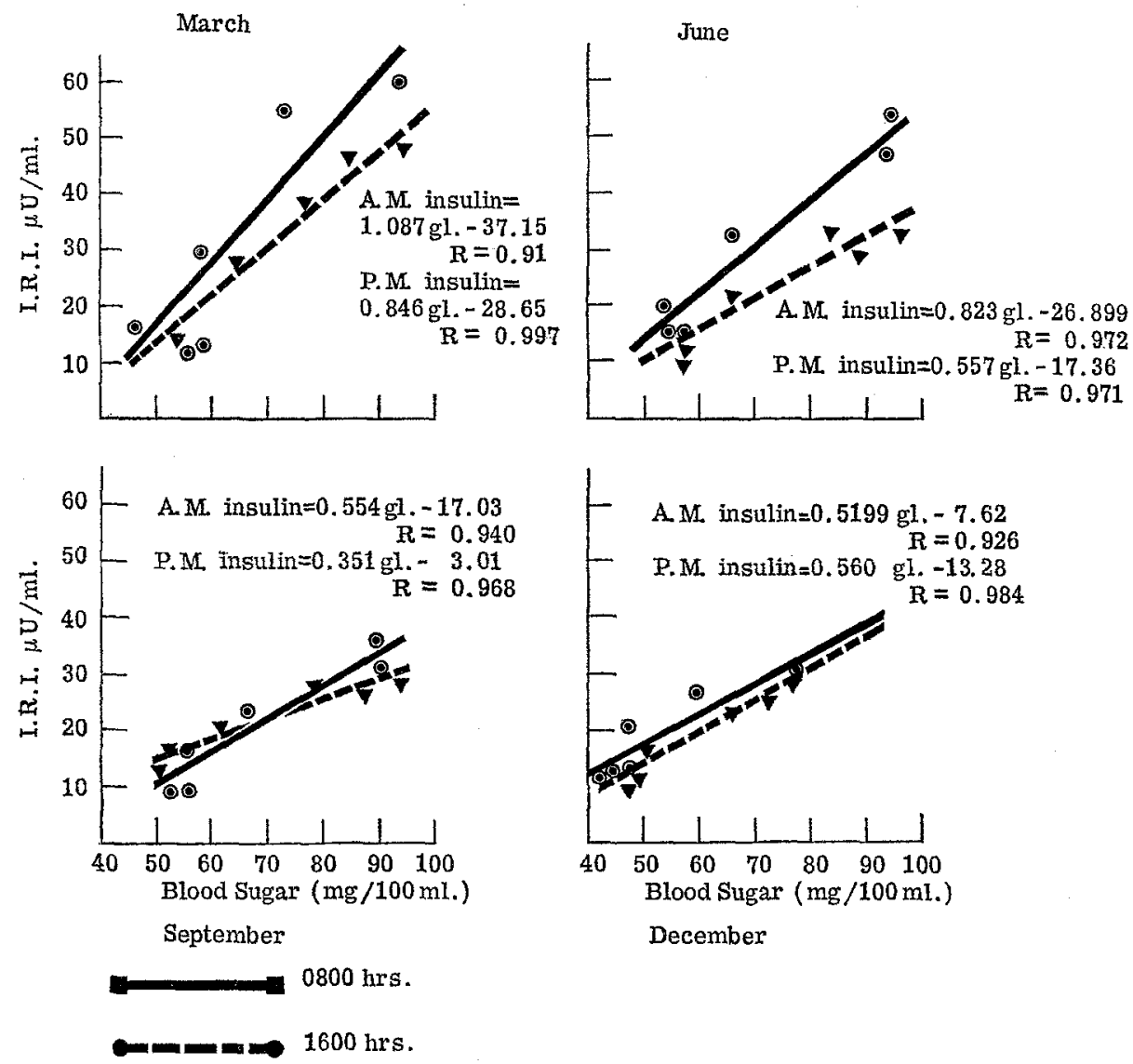

December

Fig. 1. Calculated regression lines for insulin/glucose relationship by time of day and by season. The points represent mean values for each time point of the glucose tolerance test

March and September. The morning results for September and December are similar and in these months there was little difference in the slope of the insulin/ glucose regression from morning to afternoon.

We have looked at this relationship in a slightly different way by calculating glucose/insulin ratios. To do this we found the intercept value of glucose, i.e. when insulin was zero, for each season and time of day. This value of glucose was then subtracted from

\section{Growth Hormone}

Fasting and $2^{1 / 2}$ hr growth hormone levels did not differ significantly between morning and afternoon or between seasons.

\section{Discussion}

The insulin levels during GTTs done through the year showed the same kind of diurnal pattern as those described previously $[3,7,10,11]$; the rise in insulin 
in response to glucose was delayed in the afternoon compared with the morning. These authors have also reported afternoon levels higher than the morning ones later in and persisting to the end of the test. This pattern is seen in the March, September and December tests, although the difference is only very small in the latter two, and is absent in the June test. Fig. 1 portrays the insulin/glucose relation within the glucose tolerance tests, but ignoring the temporal relations to the oral glucose stimulus. In March and June, there are higher levels of insulin for a given level of blood glucose in the morning. In September and December, however, the morning and afternoon relationships are almost indentical. Glucose insulin ratios are another way of expressing the relationship, though they can be affected by changes in numerator, denominator or in both. In the method that we have used, they can also be affected by variations in the value of the glucose intercept and we cannot tell whether such variations are environmentally determined or are simply the result of statistical artefact. There were considerable seasonal variations in the glucose/insulin ratio, with the lowest values in March, probably the time when outside activity was greatest.

Whatever the explanation for the changing glucose-insulin ratio, it is interesting that there can be such a change and of considerable degree. Such a variation has been demonstrated within individuals when given different oral glucose loads $[4,5]$, in obese individuals subjected to physical training [1], between intravenous and oral administration of glucose [8] and, in the present study, with environmental changes. All these factors must be borne in mind, therefore, when attempts are made to assess the glucose/insulin ratio in individuals or groups and its relationship to diabetes.
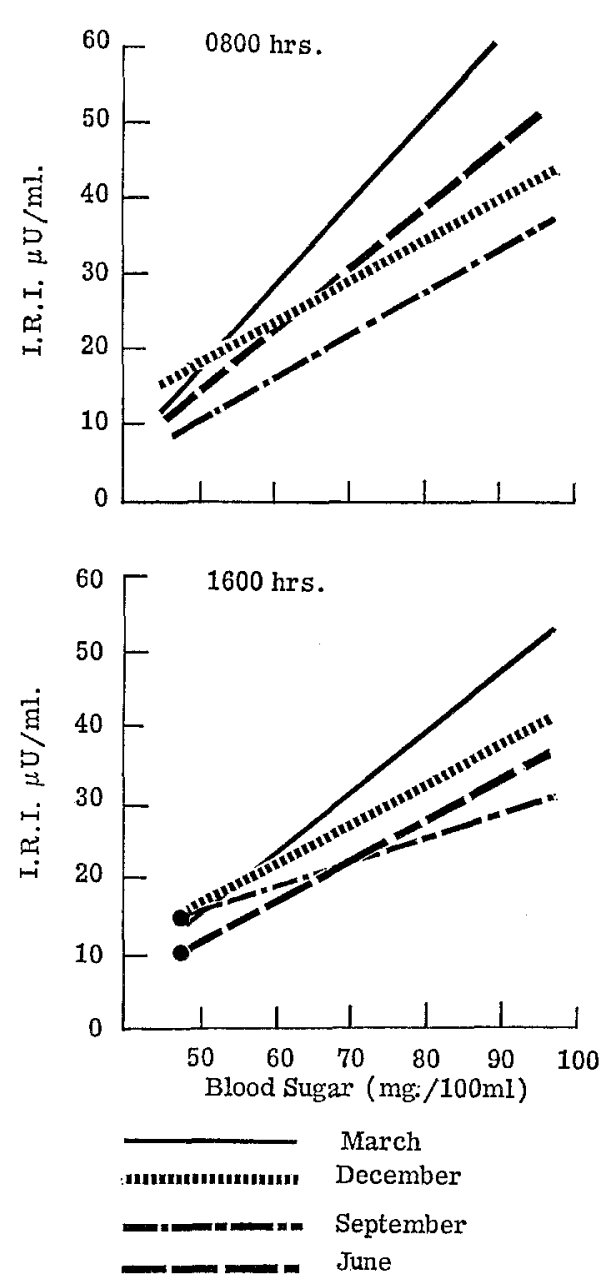

Fig. 2. The calculated regression lines (Fig. 1) displayed for morning and afternoon separately, by season

Table 2. (a) Mean \pm S.D. glucoselinsulin ratio by month and time of day. (b) Values of

' $t$ ' and ' $p$ ' for various statistical (using Student's t test)

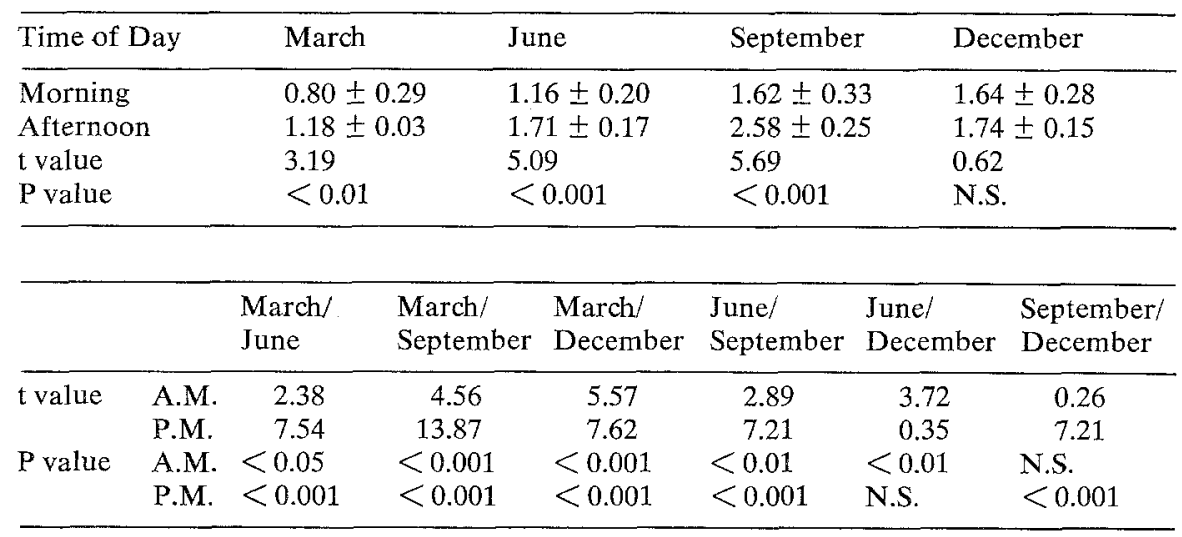




\section{References}

1. Björntörp, P., de Jounge, K., Sjöström, L., Sullivan, L.: The effect of physical training on insulin production in obesity. Metabolism 19, 631-638 (1970)

2. Campbell, I. T., Jarrett, R. J., Keen, H.: Diurnal and seasonal variation in oral glucose tolerance: Studies in the antarctic. Diabetologia 11, 139-145 (1975)

3. Carroll, K. F., Nestel, P. J.: Diurnal variation in glucose tolerance and in insulin secretion in man. Diabetes $\mathbf{2 2}$, 333-348 (1973)

4. Castro, A., Scott, J. P., Grettie, D. P., Macfarlane, D., Bailey, R. E.: Plasma insulin and glucose responses of healthy subjects to varying glucose loads during threehour oral glucose tolerance tests. Diabetes 19, 842-851 (1970)

5. Christensen, N. J., Ørskov, H., Hansen, A. P.: Significance of glucose load in oral glucose tolerance tests. Acta. med. scand. 192, 337-342 (1972)

6. Hartog, M., Gaafar, M. A., Meissner, B., Fraser, R.: Immunoassay of serum growth hormone in acromegalic patients. Brit. med. J. 1964 II, 1229-1232

7. Jarrett, R. J., Baker, I. A., Keen, H., Oakley, N. W.: Diurnal variation in oral glucose tolerance: blood sugar and plasma insulin levels morning, afternoon and evening. Brit. med. J. 1972 I, 199-201
8. McIntyre, N., Holdsworth, C. D., Turner, D. S.: New interpretation of oral glucose tolerance. Lancet 1964 II, $20-21$

9. Morgan, C. R., Lazarow, A.: Immunoassay of insulin with a two antibody system. Plasma insulin levels of normal, subdiabetic and diabetic rats. Diabetes 12, 115-126 (1963)

10. Oakley, N. W., Monier, D., Wynn, V.: Diurnal variation in oral glucose tolerance: insulin and growth hormone changes with special reference to women taking oral contraceptives. Diabetologia 9, 235-238 (1973)

11. Zimmet, P. Z., Wall, J. R., Rome, R., Stimmler, L., Jarrett, R. J.: Diurnal variation in glucose tolerance: associated changes in plasma insulin, growth hormone, and non esterified fatty acids. Brit. med. J, 1974 I, 485-488

Dr. R. J. Jarrett

Dept. of Medicine

Guy's Hospital Medical School

London Bridge, SE1 9RT

England 